\title{
Identifying Core Reference Competencies from an Employers' Perspective: Implications for Instruction
}

\section{Laura Saunders}

\begin{abstract}
Reference services are in transition. Impacted by advances in technology, changing user expectations, and the migration to greater provision of online and distance service, reference in academic libraries today is not the same service it was even just a decade ago. Most literature looks at reference competencies either for a specific service model such as virtual reference, or a specific type of library like an academic health or law library. Despite the changing nature of the job, few studies have considered reference competencies more broadly from the employer's point of view. This study reports the preliminary results of a survey of current reference librarians and hiring managers to answer the following questions: What knowledge, skills, and competencies do current practitioners and hiring managers believe to be valuable for the provision of reference services now and into the future? What areas do managers find lacking or underdeveloped in their new hires? How well do current library science programs prepare students to meet employer expectations for reference positions?
\end{abstract}

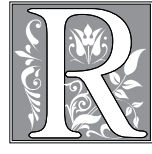

eference services, like most other library services, are in transition. Impacted by advances in technology, changing user expectations, and the migration to greater provision of online and distance service, reference in academic libraries today is not the same service it was even just a decade ago. To meet these changing needs, many libraries are focusing their energies on adapting and reinventing the reference service model to suit current patrons. Depending on the size and type of library, librarians have experimented with many different models, ranging from tiered service, which breaks reference into discrete areas whereby directional, equipment, and some ready-reference questions are handled by paraprofessionals and more complex questions are referred to professional librarians, to consolidated service points where previously separate functions such as circulation, ILL, technology help and reference are co-located at one desk. Some libraries have implemented roving reference and

Laura Saunders is Assistant Professor in the Graduate School of Library and Information Science at Simmons College; e-mail: laura.saunders@simmons.edu. (c) 2012 Laura Saunders, Attribution-NonCommercial (http://creativecommons.org/licenses/by-nc-sa/3.0/) CC BY-NC 
other outreach models, which bring the service away from the desk and out into the stacks, or even outside the library itself, to meet users where they are.

New technologies allow for even greater flexibility in providing remote services. Many libraries now reach out to distant patrons with digital reference services, often with extended hours, through chat, text, and other more sophisticated systems that allow for cobrowsing and other kinds of application sharing. In addition to these question-answering services, many reference librarians find themselves taking on additional responsibilities, such as collection development, which often requires negotiating with vendors of electronic resources, and instruction, ranging from library tours and workshops to formal classroom instruction. Such changes in the service model and delivery necessarily entail different skills, competencies, and knowledge than the traditional emphasis on familiarity with particular reference resources and negotiation of the face-to-face reference interview. ${ }^{1}$ These changes not only pose challenges for librarians in the field as they strive to keep up with the transitions, they also have implications for the training of new reference librarians. In light of the flux in the field, what knowledge, skills, and competencies are most relevant to librarians entering the profession right now, and how well are library schools preparing students in those areas?

Most literature looks at reference competencies either for a specific service model such as virtual reference ${ }^{2}$ or a specific type of library like an academic health or law library. ${ }^{3}$ Despite the changing nature of the job, few studies have considered reference competencies more broadly from the employer's point of view. What knowledge, skills, and competencies do current practitioners and hiring managers believe to be valuable for the provision of reference services now and into the future? What areas do managers find lacking or underdeveloped in their new hires? How well do current library science programs prepare students to meet employer expectations for reference positions? This study aims to fill a void in the literature by surveying current reference librarians, including hiring managers, to answer the above questions and determine which are the most important competencies for current academic reference librarians. This article reports the preliminary results of this survey, with a focus on the most highly valued competencies, and the employers' perspective on new hire abilities in those areas. This survey was undertaken in conjunction with a parallel study of public reference librarians, and subsequent reports will analyze the results of both settings. The results of this study will be of interest to library directors and reference department managers by giving them insight into what their colleagues perceive to be the most important areas of knowledge and skill for provision of this service and might also help them in focusing job ads and making hiring decisions. Library students and career changers with an interest in reference services will also be interested in these results as a way to help them target and develop skills and competencies to make them more competitive in the job market. Finally, library school instructors and deans might use the results of this study to determine how well their curriculum is meeting the expectations and demands of their students' future employers.

\section{Literature Review}

The reference transaction, in which the librarian acts as an information consultant to "recommend, interpret, evaluate, and/or use information resources to help others to meet particular information needs, ${ }^{4}$ implies a knowledge of information sources and how to search them, as well as the ability to communicate information to patrons effectively. In addition, reference librarians typically perform other functions such as collection development, instruction, development of tools such as Web sites and pathfind- 
ers, outreach activities, and assessment and evaluation of all of these areas, each of which entails its own set of skills and competencies. The Reference and User Services Association (RUSA), a division of the American Library Association, offers two broad sets of guidelines that outline competencies and behaviors for reference librarians. ${ }^{5}$ Broadly speaking, most writing about reference competencies can be grouped as dealing with interpersonal and communication skills, technology skills, resource and subject knowledge, and additional areas.

\section{Interpersonal and Communication Skills}

A major component of reference work involves direct service to and interaction with patrons. As a result, interpersonal and communication skills, including the ability to build relationships with colleagues and with users, through active listening and inquiring as well as effective communication of information, are widely acknowledged to form a core set of competencies for reference librarians. ${ }^{6}$ Indeed, although accurate answers to informational queries are important, establishing a rapport with patrons is perhaps more important and has been shown to influence a patron's willingness to return to the same librarian for further help. ${ }^{7}$ As reference services increasingly move online, interpersonal and communication skills may be even more important, as librarians are communicating with patrons in many different ways and often without the support of nonverbal cues. ${ }^{8}$ In fact, a review of job postings finds that interpersonal skills and behavioral characteristics each appeared in more than 60 percent of job postings in 2004, nearly triple what they were in 1974, suggesting that such skills are increasingly valued by employers. ${ }^{9}$

One challenge is to determine how some interpersonal and communication skills translate to the online environment. RUSA has adapted its behavioral guidelines to reflect new technology, for instance suggesting that online approachability consists of making sure links to online services are easy to find and free of jargon..$^{10}$ Other studies have attempted to develop entire sets of guidelines and competencies for provision of remote reference services, which include learning the software involved, becoming familiar with basic chat and text conventions, developing online communication skills, and working in a team or collaborative environment. ${ }^{11}$ Further, to extend their reach and interact with users in familiar and convenient ways, librarians now must master blogging, wikis, chat, texting, RSS, and a whole host of other services. ${ }^{12}$

Technical knowledge necessary to reference is not confined to end-user applications or various communication softwares, however. The technical skills expected of reference librarians ranges from the use of e-mail and the Internet, to planning for automation of services, to developing Web sites and other Webbased materials; and Mahmood found that information technology competencies account for seven of the top ten competencies for academic librarians. ${ }^{13}$ McCarthy includes several additional areas of importance, such as understanding and using learning objects and data sets, creation of products such as Web sites and subject portals, and development of access systems. ${ }^{14}$ Not surprisingly, a comparative review of job ads reveals a large increase in the demand for technological skills for librarians, and even some of the interpersonal and behavioral competencies listed in job ads, such as flexibility and creativity, appear to be related to a need to learn about and adapt to changes in technology. ${ }^{15}$ Not only has more rapid and widespread access to information changed user expectations, it also means that librarians must constantly learn and implement new technologies to meet those expectations and provide relevant, cutting-edge service. ${ }^{16}$

Finally, reference librarians are expected to have a host of other competencies and knowledge areas that extend well be- 
yond the traditional question-answering services. Wang, Tang, and Knight find that instruction has been a core component of reference job descriptions since the mid-1960s. ${ }^{17}$ With increased emphasis on information literacy, responsibilities for instruction continue to grow as reflected in job titles and even the creation of separate positions for instruction. ${ }^{18}$ Whether working as subject specialists or generalists, reference librarians often are involved in collection development and must acquire new competencies for developing and managing online or digital reference collections, including negotiating with vendors, as well as selecting, evaluating, and acquiring resources. ${ }^{19}$ Finally, as more reference departments hire paraprofessionals and student workers for some functions, some reference librarians have to take on management and supervisory responsibilities. In addition to day-to-day management functions such as scheduling, budgeting, hiring and training, these librarians must engage in strategic planning, assessment, conflict resolution, and negotiation with internal and external constituents. ${ }^{20}$ Indeed, Osa (2003) and Unaeze (2003) argue that reference librarians will need to move beyond management functions to leadership, whereby they build relationships and create visions to move followers toward action for change. ${ }^{21}$

\section{Education for Reference}

In considering how reference work is changing, it is also worthwhile to examine how challenges in the field are impacting how reference is taught in the classroom. Indeed, the literature on reference education confirms that the changing nature of the service is creating challenges for teaching reference. One perennial challenge in reference courses is the amount of material that most instructors believe must be covered and, in particular, finding a balance between introducing students to the reference sources they will be using on the job and discussing the service areas and expectations, as well as balancing between theory and practice. ${ }^{22}$ Powell and Raber note that a "knowledge of reference sources remains central to basic reference courses" and, as the number and format of information sources increases, so does the pressure to ensure that students are well grounded in using these various sources. ${ }^{23}$ Yet a discourse exists as to how much time should be spent on individual source titles and how much time should be spent on overall types of sources, as well as debate over how extensively to cover print versus electronic resources. ${ }^{24}$ Some practitioners suggest that resource familiarity depends on local collections and access and therefore must be learned mostly on the job rather than in the classroom. ${ }^{25}$

Changes in technology pose a host of other challenges for instructors beyond simple coverage of electronic reference sources. To begin with, students and instructors vary in their technical abilities, and instructors must determine how to integrate technology into the course and bring novice students up to par while still challenging more advanced students. In addition, reference instructors have to address technology associated with the delivery of virtual and remote reference, including social media, chat, instant messaging, and phones. ${ }^{26}$ Finally, as more library schools offer distance learning courses, instructors have to determine how best to deliver content and promote learning in an online environment. ${ }^{27}$ Agosto et al. note a number of challenges for teaching reference, including the changing nature of the field, technological changes, and a diverse student body, as well as the tensions of finding a balance between teaching sources versus services and theory versus practice. ${ }^{28}$ Add into the equation the expectations of employers, and instructors of reference face enormous demands for preparing a new generation of librarians.

\section{Research Procedures}

The purpose of this study is to gather feedback from current reference librarians 
and those hiring reference librarians to determine which competencies are most needed in the field right now and which are predicted to be most necessary in the near future. In particular, this study aims to answer the following research questions:

- Which competencies do current academic reference librarians deem most important for those coming into the field?

- What competencies, if any, do current reference librarians see lacking, or needing to be more fully developed, in their new hires?

- What are the implications for library school curricula?

Because the objective of this study is to develop a baseline set of competencies for academic reference librarians, it was determined that a brief survey administered to a large nationwide sample would yield the most useful results. A small sample, or one that was geographically or institution specific, might only reflect local needs and practices that could not be generalized. If participants in a large nationwide sample tend to form a consensus on the skills and qualities necessary for an academic reference librarian, it is more likely that those competencies have external validity. The author limited the population to four-year nonprofit institutions with an undergraduate component. In other words, community colleges and stand-alone graduate institutions are not included. Finally, the author chose to focus on libraries not in the Association of Research Libraries (ARL). While ARL libraries offer much in the way of best practices for other institutions, they tend to have much larger staffs and budgets than the majority of academic libraries; thus, they might be better studied separately. The author is undertaking a separate study to examine reference practices in ARL libraries and their implications for the future of reference. The population for this study, therefore, is non-ARL academic libraries.

A list of all academic libraries in the United States arranged by state was accessed from LibWeb (http://lists.webjunction.org/libweb/Academic_main. $\mathrm{html}$ ). From this list, a random sample of up to ten institutions from each state was drawn. The final study sample consisted of 457 academic libraries. The objective was to collect opinions of librarians currently practicing in the field of reference, as well as those who might have authority to hire new reference librarians. The author searched the Web site of each institution to locate the name of at least one, and up to two, librarians for each library. Every effort was made to identify the reference librarian or reference manager at each library, but in some cases the invitation was sent to the library director, assistant director, or a public services librarian, with the request that they forward the survey to the appropriate person. Each librarian received an e-mail explaining the purpose of the study and inviting them to participate by following an embedded link to a Web-based survey.

The survey asked librarians to choose all competencies they considered necessary for reference librarians in three categories: general, technology, and personal/interpersonal. This original list of competencies is based largely on the RUSA guidelines, with some additional competencies or skills culled from the literature review. Table 1 shows the list of competencies included in the survey. Several steps were taken to increase reliability and validity. To begin with, the survey was developed in conjunction with another faculty member and questions were pretested to ensure they were clear and understandable. In addition to checking off as many competencies as they saw necessary from the list, participants were also asked to indicate which two or three skills on each list are most important. This follow-up question helps establish validity for the responses. If the competencies highlighted as most important correspond to the competencies receiving the highest numbers of votes from the checklist, it stands to reason that those competencies are the most highly valued 
by this group. Finally, open-ended questions asked librarians to describe their typical activities and anything they see lacking in new reference librarians. Again, these follow-up questions allowed the researcher to check answers for reliability.

The survey was anonymous, but participants were offered a chance to enter a drawing for a \$25 Amazon.com gift card. The initial invitation was followed up two weeks later by a second invitation to increase response rate. Two weeks after that, the survey was closed and the results analyzed. Close-ended questions were analyzed using descriptive statistics including frequency counts and percentages, while open-ended questions were coded using a content analysis.

\section{Findings}

The response rate for this survey was good. A total of 436 librarians from 212 institutions participated. Using the institution as the unit of analysis, there was a response rate of 46.4 percent. Responses came from a range of institution types. Likewise, the participants varied widely in terms of age and length of experience in the field, as illustrated in figures 1 through 3 . While the majority of respondents fell between 31 and 60 years of age, 2 participants indicated that they are younger than 25 , and 3 are older than 71 . In terms of experience, the participants range fairly evenly from less than one year to more than 30 years, with the highest proportion of participants having between 8 and 15 years of experience. Finally, 76.4 percent of the respondents are female, and 96.8 percent hold an MLS degree.

The main portion of the survey asked participants to select any competencies they believe to be necessary for reference librarians in three categories: general, technology, and personal/interpersonal, as laid out in table 1 . It is worth noting that all competencies in all categories got at least some votes. This finding suggests that all

\begin{tabular}{|l|l|l|}
\hline \multicolumn{3}{|c|}{ TABLE 1 } \\
\hline General & Technology & Personal/Interpersonal \\
\hline Second master's degree & Online searching & Verbal communication \\
\hline Budgeting & Programming & Written communication \\
\hline Foreign language & Web design & Listening \\
\hline Marketing & Web maintenance & Working in teams \\
\hline Supervisory experience & Social media & Approachability \\
\hline $\begin{array}{l}\text { Ability to conduct research/ } \\
\text { publish }\end{array}$ & Hardware troubleshooting & $\begin{array}{l}\text { Comfort with instruction/ } \\
\text { teaching }\end{array}$ \\
\hline Knowledge of cataloging & Software troubleshooting & Self-motivated \\
\hline Assessment/evaluation & Chat/IM & Stress management \\
\hline Customer service & & $\begin{array}{l}\text { Building relationships with } \\
\text { coworkers }\end{array}$ \\
\hline Familiarity with paper sources & & $\begin{array}{l}\text { Building relationships with } \\
\text { other professional colleagues }\end{array}$ \\
\hline Familiarity with online sources & & Conflict management \\
\hline Search skills & & Adaptability/flexibility \\
\hline Negotiating & & Sense of humor \\
\hline Current events awareness & & Organizational awareness \\
\hline Traditional reference interview & & \\
\hline
\end{tabular}


of the competencies have some value, and what is most important for any reference librarian will depend to some extent on the mission and organizational culture in which they work, as well as local needs and practices. That said, certain competencies received a much higher proportion of the votes than others, indicating that these competencies likely are important for all reference librarians regardless of location. The following sections analyze the findings by competency category.

\section{General Skills}

The findings for competencies in the general category were the most widely dispersed. Four competencies in this category received votes over 75 percent, suggesting that these might be the most important and most widely sought competencies for academic reference librarians. At the top of this list is search skills (95.6\%), followed very closely by customer service $(94 \%)$ and familiarity with online reference sources (93.4\%). Though not as highly rated as the other three, ability to conduct a reference interview is still viewed as an important competency, with 75.5 percent of respondents. In the follow-up question, these four were also chosen as the most important of the fifteen general competencies by the majority of the participants. Three other competencies-knowledge of print reference sources, current events awareness, and the ability to engage in assessment and evaluation-likewise gained over 50 percent of the votes.

On the opposite end of the spectrum, knowledge of a foreign language received
FIGURE 1

\section{Respondents by Gender}

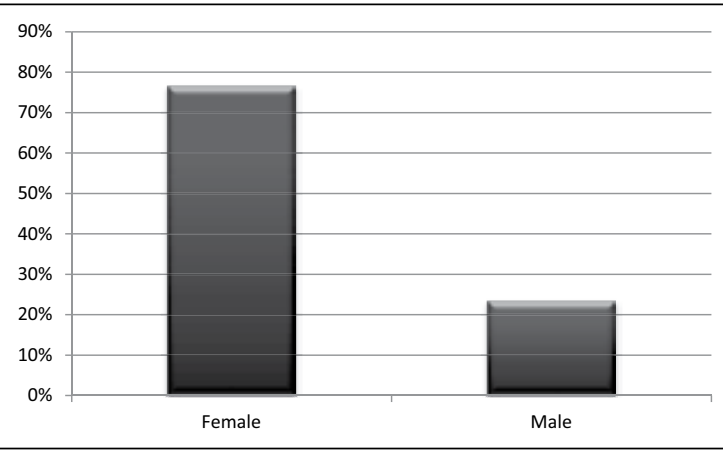

FIGURE 2

Respondents by Age

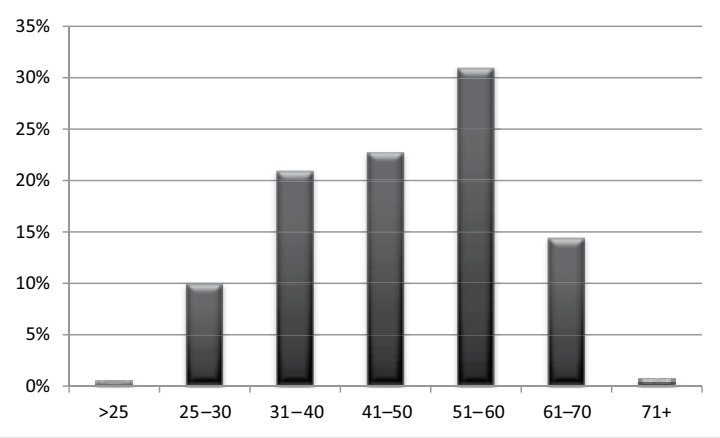

FIGURE 3

Respondents by Years in the Profession

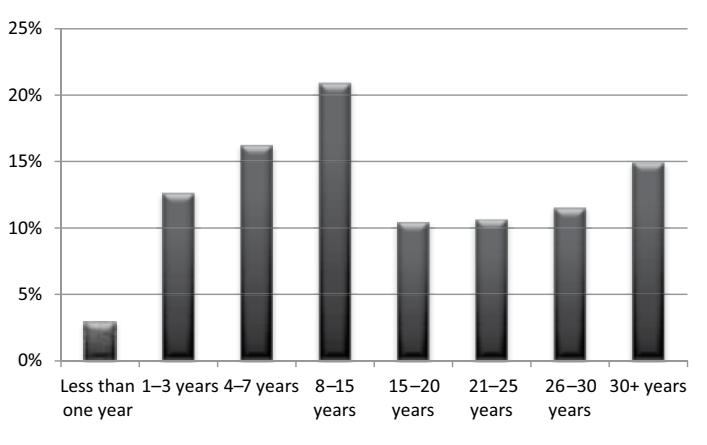

the least votes overall, at 38 (11.9\%). Budgeting and possession of a second master's degree were also not highly rated, at 24.8 percent and 28.2 percent of votes respectively. All other competencies ranked in between these extremes, with generally between 25 percent and 35 per- 
cent of the votes, as illustrated by figure 1 . It is worth considering, however, that the relative importance of some competencies is likely influenced by the type of library. Cross-tabulation and chi-square analysis of certain variables reveals a correlation between Carnegie classification of the institution and likelihood of choosing certain competencies as essential. For instance, a chi-square analysis of the importance of a second master's degree with Carnegie classification of bachelor and doctoral institutions revealed a $p$ score of .007. A similar analysis for Carnegie classification and importance of research and publication resulted in a $p$ score of .028. These findings suggest that some institutions place a higher value on some competencies. Perhaps a doctoral institution will be more likely to expect staff to support in-depth research that requires greater content knowledge and therefore will be more apt to seek applicants with advanced degrees in the subjects. Applicants and new hires must consider the type of institution when weighing the importance of each skill or area of knowledge.

\section{Technology Skills}

Unlike the competencies in the general category, figure 5 demonstrates that the technology skills were much more closely clustered, with one exception. Programming skills appear to be the least important of technology skills for reference librarians, garnering only 8 percent of the votes. All other competencies were rated as important by over 49 percent of the participants. By far, the most highly rated skill is online searching abilities, chosen by 98.4 percent of participants, likely reflecting the prevalence of online and electronic resources. Next most popular is software troubleshooting, followed by knowledge of chat/IM and social media technologies. Finally, Web design and Web maintenance were essentially tied, 53 percent and 52.4 percent of votes respectively. The areas of design and maintenance were separated in the survey under the assumption that some reference librarians might be responsible for adding content or checking and fixing links but might not be designing Web pages from scratch. In the end, however, these two areas seem to be equally important. These findings were borne out in the follow-up question asking participants to choose the two or three most important competencies from the list.

\section{Personal/Interpersonal Skills}

Like the technology competencies, the personal and interpersonal competencies were closely clustered. In fact, all of

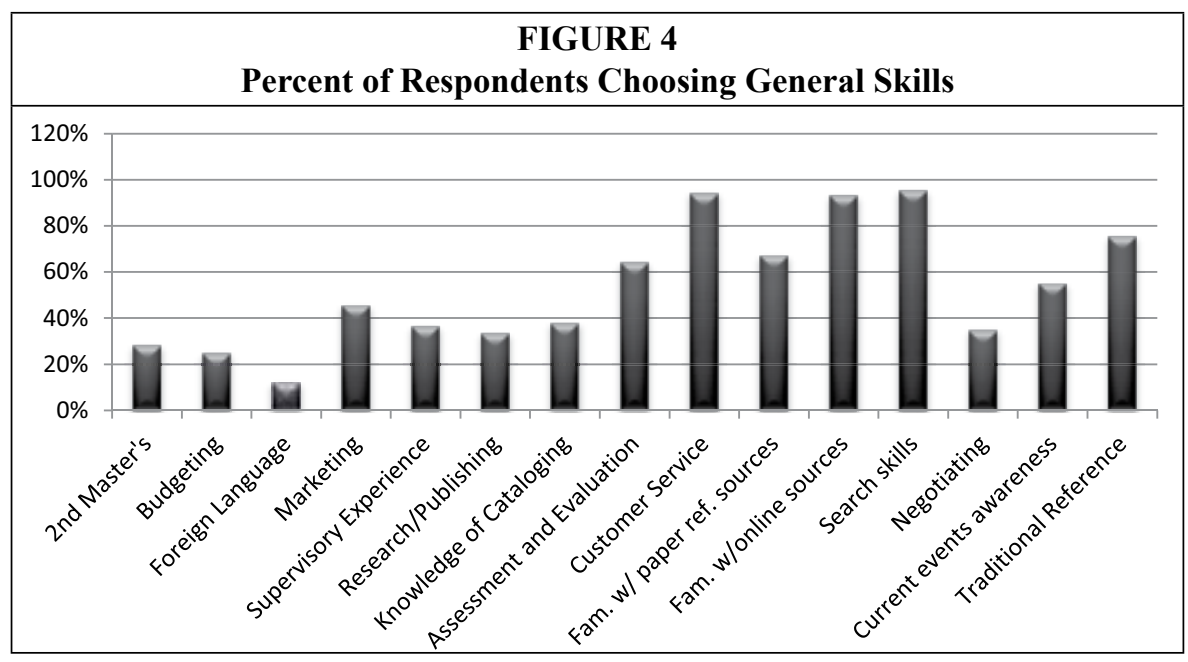




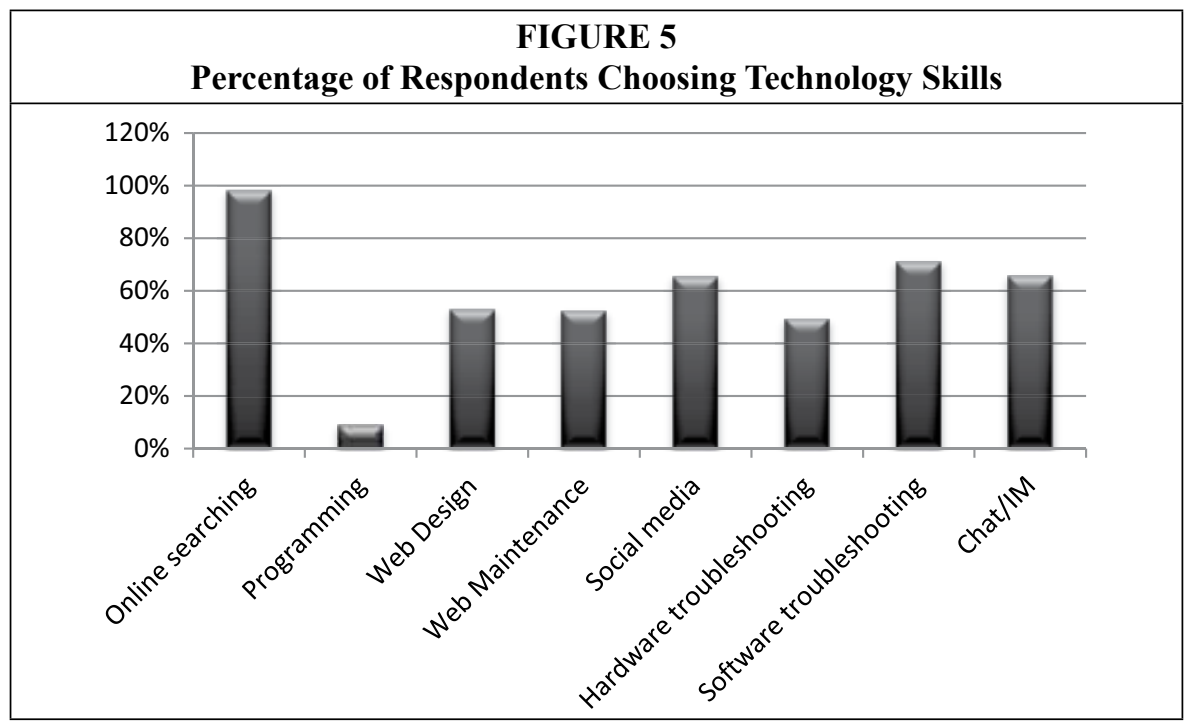

the competencies in this category were chosen as important by more than 60 percent of the participants, as depicted in figure 6 . The top five competencies, all chosen by more than 90 percent of the participants, are verbal communication skills, listening, approachability, comfort with instruction, and adaptability/flexibility. These five were closely followed by written communication skills and sense of humor, which received 87.8 percent and 85 percent of votes respectively. The two lowest scoring competencies were conflict management and stress management, but again it must be stressed that both still received more than 60 percent of the votes and thus must still be considered valuable skills. Once again, these findings were confirmed by the follow-up question, where the same five competencies were rated as most important.

\section{Discussion}

The findings of this study indicate that a current range of competencies across different areas, with a particular emphasis on interpersonal communication skills, and the technical savvy to at least trouble-

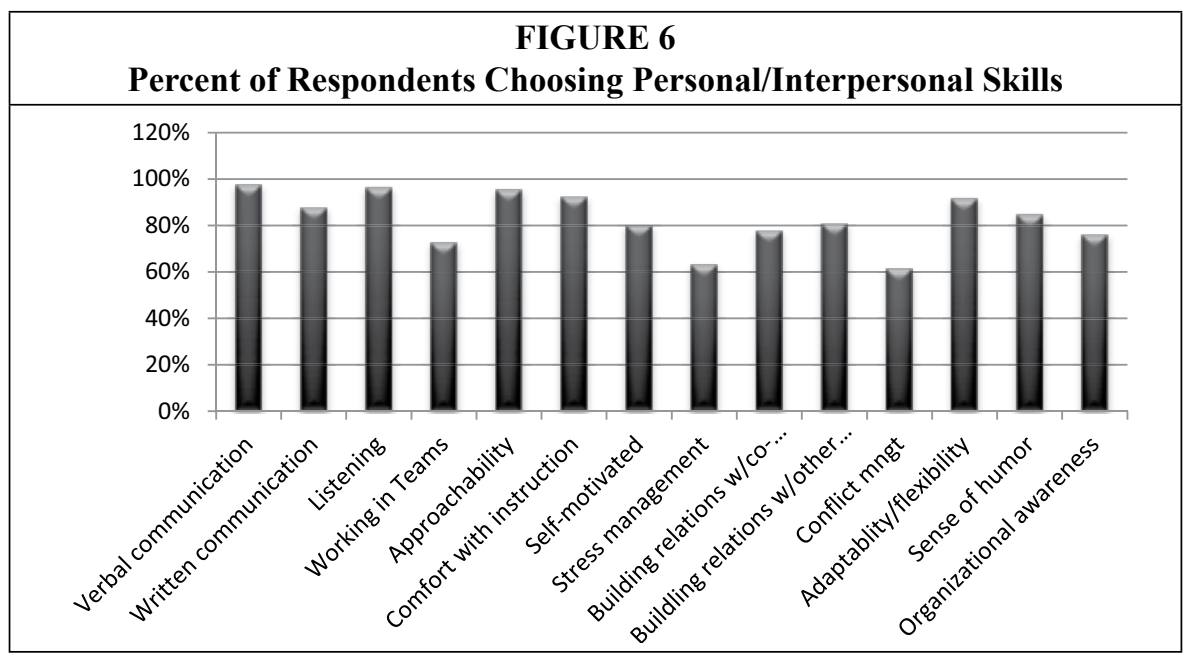


shoot problems if not develop new tools are necessary to function successfully as a reference librarian in an academic library. These findings are not surprising. It stands to reason that, as frontline service professionals who interact directly with patrons, reference librarians must have a strong customer service orientation and that the rapid and ubiquitous development of technology has had an impact on the provision of reference services, as reflected in the importance placed on online search skills, Web page design and maintenance, and the ability to troubleshoot hardware and software. While not surprising, these findings do have implications for reference instruction and might offer some guidance for new and upcoming reference librarians of what skills they should focus on and how they should structure their program of study.

\section{Content}

To begin with, the fact that so many of the competencies were widely agreed on as important seems to confirm the lament of reference instructors that reference is a content-heavy course with a lot to "cover." If reference librarians must be competent searchers with knowledge of resources, as well as strong searching, technology, and interpersonal skills, the suggestion is that their instructors must address all of these topics within the reference course or, more broadly, through their program of study. Further, while new content in the form of technological resources and skills have been added, there is little evidence that other content is being eliminated. Rather, the findings suggest that students still need to learn many of the "traditional" competencies, such as the reference interview and the associated skills of listening, approachability, and communication, although they may need to be able to apply those skills in formats other than just face-to-face.

Similarly, while the literature suggests that some reference instructors are debating the balance of instruction about sources and, in particular, the value of introducing students to print resources in the classroom, ${ }^{29}$ the findings here show that librarians in the field still believe knowledge of both online and print resources to be important. Not only did 66.9 percent of respondents say that reference librarians need to be familiar with print sources, this was a recurring theme in the open-ended questions as well, with forty-three respondents (14\%) asserting that new hires are either unable or unwilling to use print resources. These participants suggested that some new hires "are as afraid of print sources as earlier iterations of librarians were of computer-based sources," and that they "don't know how to answer a question without a computer." Interestingly, chisquare and cross-tabulations revealed no correlation with either age or length of time in the profession and belief that print resources are important. In other words, it does not appear to be the case that only older librarians who might themselves be less familiar with online resources are advocating for the "good old days" of print.

It is important to note that participants are not necessarily advocating for memorization of individual titles or core lists of reference resources. Rather, they seem to be highlighting the necessity for librarians to understand and be able to use different formats and types of resources efficiently and effectively, which suggests that an overview of the structure and use of both electronic and print resources is still a necessary part of the curriculum. In terms of online sources, knowledge of the resources must be coupled with ability to search. In open-ended responses, participants specifically highlighted the importance of understanding how to use a thesaurus to find controlled vocabularies, sophisticated use of Boolean or set theory searching, as well as proximity and field searching within specialized databases. Once again, some respondents showed concern that some new hires lacked a basic understanding of cataloging and classification principles and sophisticated 
search strategies that will allow them to search online sources effectively. Other respondents felt that some new hires are too reliant on Google and the free Web when searching and do not seem to be familiar with the subject databases. As one participant states, if librarians do not search beyond Google and the visible Web, they are "no more useful than the students they're trying to help." Once again, these concerns highlight the need for reference instruction to address these areas to ensure graduates possess the skills employers seek.

At the same time, instructors also have to address other new technologies and online service outlets. As the findings show, librarians must also be comfortable reaching out to users and communicating with them through social media sites such as Facebook and Twitter as well as through chat and instant messaging. While there is a high level of agreement on the importance of these tools, unlike with print reference sources there does appear to be a correlation between age of the librarian and tendency to choose chat and instant messaging as important. A chi-square analysis of age and chat resulted in a $p$ score of .001, suggesting that older librarians are less likely to value chat and instant messaging. Nevertheless, with 65.6 percent of respondents overall indicating that chat is important, it would appear that this is an area that must be addressed somewhere within a reference librarian's program of study. In fact, Mon et al. find that reference courses largely do address various types of digital reference but acknowledge once again that instructors are challenged to balance these new forms of reference in addition to the traditional methods of service delivery. In fact, while telephone reference remains the most highly used form of remote reference in public libraries, it was the least covered in reference syllabi. ${ }^{30}$

\section{Interpersonal Skills}

One question this survey raises is the place of interpersonal skills in the ref- erence curriculum. It is clear from the findings that interpersonal and communication skills are among the most important for the reference librarian, and 22 percent of respondents indicated their belief that new hires did not exhibit strong competency in these areas. Nevertheless, little research has been done about how to teach such "soft" skills in the classroom. To what extent do reference courses address these skills, and how does one teach, for instance, approachability? In their review of reference course syllabi, Powell and Raber reviewed 24 course objectives in the four categories of reference skills, knowledge of sources, reference services, and trends and issues. ${ }^{31}$ None of these objectives describe the sort of soft skills indicated as important by participants in this survey. Granted, topics such as the reference interview or user needs might incorporate discussions of communication skills, approachability, listening and so on, but these topics do not appear to be addressed as separate components. While discussing interpersonal skills and customer service in the context of topics such as the reference interview is useful in highlighting the importance of those skills, it does not allow students to practice or improve their own skills. In addition, if interpersonal skills are not identified as objectives, students may not be receiving direct instruction or feedback in those areas. For example, Roy contends that answering questions posted to online question boards allows students to practice some of the interpersonal skills from the RUSA behavior guidelines, such as greeting the questioner or closing with a friendly salutation. However, it is unclear from the article whether the students are graded on or given feedback about these aspects of their answer. ${ }^{32}$ Grealy is one of the only authors directly to address interpersonal skills in reference education. She describes using role-playing and simulation exercises to proximate a real-world reference environment, and she stresses the importance of behavioral aspects in the simulated interactions. Stu- 
dents also offer each other peer reviews, with attention to interpersonal aspects of the interactions. ${ }^{33}$ Certainly, this is a time-consuming assignment, but it not only addresses communication and interpersonal skills, it allows students to model the behaviors rather than just read about and discuss them. The scarcity of literature on the topic begs the question of the extent to which these skills are incorporated into reference curricula. A future study might investigate whether and how library curricula address interpersonal and other "soft" skills.

\section{Additional Competencies}

Finally, the findings highlight the need for reference librarians to develop competencies that extend beyond the basic question-answering service that is usually associated with reference. One of the most highly rated areas is comfort with instruction and teaching. Not only did 92.2 percent of respondents choose instruction as an important competency, 26 percent of those chose it as one of the three most important. This finding reflects the trend of "nearly ubiquitous responsibility for instruction that accompanies academic reference positions" and highlights the need for students to develop competencies in this area. ${ }^{34}$ Nevertheless, the literature of library and information science suggests that students are not adequately prepared for teaching, and in open-ended questions 11 percent of respondents to this survey suggested that their new hires lacked skills in this area. ${ }^{35}$ Similarly, most reference librarians must have some ability to design and maintain Web pages, as well as help patrons with hardware and software troubleshooting. Many reference librarians have supervisory responsibilities and are involved in hiring, training, and scheduling staff, as well as administering a budget. Finally, though it is somewhat outside the scope of this study, the survey also revealed that reference is increasingly becoming a multifunction position. In open-ended responses to areas of re- sponsibility, reference librarians indicate that, in addition to reference duties, many also have responsibility working in and/ or overseeing circulation, interlibrary loan, cataloging, and archives. Certainly, each of these areas has unique areas of knowledge and skills required. In fact, it seems highly unlikely that a traditional basic reference course could do much in the way of addressing most of these areas beyond a brief and relatively superficial overview. Instead, it will be important for reference instructors and aspiring reference librarians to work together to develop a program of study that addresses these skills outside the reference course. However, to do that, students and faculty must be aware of the current demands, and library schools must ensure that their curriculum offers courses that address these areas.

\section{Conclusion}

This study highlights that employers expect a wide range of competencies ranging from facility with technology to interpersonal and communication skills from their reference librarians. It is worthwhile for new and soon-to-be graduates, as well as the faculty who teach them, to be aware of current demands in the field to ensure that they are developing the skills that employers value. Further, new graduates should be aware that some employers might be unsure of their grounding in traditional reference sources or their ability to move beyond Google-style searches, and, as such, they may want to emphasize their knowledge and abilities in these areas on application materials and during interviews. Equally important, this study seems to confirm that more traditional competencies are not necessarily being replaced, but only added to, as technology and other changes in the field demand new skills and areas of knowledge. This reality poses a challenge to instructors of reference, who already feel burdened by the amount of material they must address within their courses. More sources of information are 
being produced in more formats than ever before, technology continues to change at a rapid pace, requiring new sets of skills or updating and adaptation of existing skills, and reference work is expanding to take on greater responsibilities in areas such as instruction, access services, and beyond. This study establishes which competencies employers believe are most important and begins to examine the implications for teaching reference. Further studies might examine the extent to which existing courses are already addressing these areas and how programs and courses of study might be structured to build on basic reference courses to ensure that students attain proficiency in each of the competency areas.

\section{Notes}

1. Marcella Knibbe-Haanstra, "Reference Desk Dilemmas: The Impact of New Demands on Librarianship," Reference and User Services Quarterly 48 (Fall 2008): 20-25, available online at http://web.ebscohost.com/ehost/pdfviewer/ [accessed 2 March 2011]; Jenny McCarthy, "Planning a Future Workforce: An Australian Perspective," New Review of Academic Librarianship 11 (Apr. 2005): 41-56, doi:10.1080/13614530500417669 [accessed March 2, 2011].

2. Lili Luo, "Chat Reference Competencies: Identification from a Literature Review and Librarians Interviews," Reference Services Review 35 (2007): 195-209, doi: 10.1108/00907320710749137 [accessed 2 March 2011]; Jana Rona, Patrick Reakes, and Marilyn Ochoa, "Application of Reference Guidelines in Chat Reference Transactions: A Study of Online Reference Skills," College $\mathcal{E}$ Undergraduate Libraries 13 (2006): 3-23, doi:10.1300/J106v13n04@02 [accessed 2 March 2011].

3. Janene Batten and Lei Wang, "Virtual Reference Service: From Competencies to Assessment," Journal of Electronic Resources in Medical Libraries 5 (2008): 411-13, doi:10.1080/15424060802453829 [accessed 2 March 2011]; Education Section of the Business Reference and Services Section, "Core Competencies for Business Reference," Reference and User Services Quarterly 46 (Fall 2006): 40-43, available online at http://web.ebscohost.com/ehost/pdfviewer/pdfviewer?hid=7\&sid=7dea91b1538e-4fc1-a244-3d4587843031\%40sessionmgr12\&vid=8 [accessed 2 March 2011]; Nicole Mitchell, "The Changing Role of References Services in Academic Health Sciences Libraries," Public Services Quarterly 3 (2007): 235-37, http://web.ebscohost.com/ehost/pdfviewer/ pdfviewer?hid=106\&sid=7dea91b1-538e-4fc1-a244-3d4587843031\%40sessionmgr12\&vid=9 [accessed 2 March 2011]; Kay M. Todd, "Competencies of Law Librarianship: Reference, Research, and Patron Services," Legal Reference Services Quarterly 26 (2007): 7-33, doi:10.1300/J113v26n01_02 [accessed 2 March 2011].

4. Reference and User Services Association, "Definitions of Reference," available online at www.ala.org/ala/mgrps/divs/rusa/resources/guidelines/definitionsreference.cfm [accessed 2 March 2011].

5. Reference and User Services Association, "Professional Competencies for Reference and User Services Librarians," available online at www.ala.org/ala/mgrps/divs/rusa/resources/ guidelines/professional.cfm [accessed 2 March 2011]; Reference and User Services Association, "Guidelines for Behavioral Performance of Reference and Information Service Providers," available online at www.ala.org/ala/mgrps/divs/rusa/resources/guidelines/guidelinesbehavioral.cfm [accessed 2 March 2011].

6. Reference and User Services Association, "Professional Competencies;" Reference and User Services Association, "Behavioral Guidelines;" Donna Dee, "Client Service: Competencies and Communication," in Cite 30 (Sept. 2009): 22-23, available online at http://web.ebscohost.com/ehost/ pdfviewer/pdfviewer?hid=7\&sid=7dea91b1-538e-4fc1-a244-3d4587843031\%40sessionmgr12\&v id=12 [accessed 2 March 2011]; Marshall Eidson, "Using 'Emotional Intelligence' in the Reference Interview," Colorado Libraries 26 (Summer 2000): 8-10, http://0-vnweb.hwwilsonweb.com.library. simmons.edu/hww/results/results_single_fulltext.jhtmlhwwilsonid=1PWQE2SANQC0XQA3DI MSFGOADUNGIIV0 [accessed 2 March 2011]; Lorraine J. Pellack, "Interpersonal Skills in the Reference Workplace," The Reference Librarian 40 (2003): 57-70, doi:10.1300J120v40n83_06 [accessed 2 March 2011]; Christina K. Pikas, "Communication Is the Key Skill for Reference Librarians," Evidence Based Library and Information Practice 2 (2007): 88-91, available online at www.doaj.org/doaj ?func=abstract\&id=242255\&recNo=15\&toc=1 [accessed 2 March 2011]; Johannah Sherrer, "Thriving in Changing Times," The Reference Librarian, 25 (1996): 11-20, accessed March 2, 2011, available online at http://0-pdfserve.informaworld.com.library.simmons.edu/83143_751305047_928518627. pdf [accessed 2 March 2011].

7. Patricia Dewdney and Catherine Sheldrick Ross, “Flying a Light Aircraft: Reference Service 


\section{Identifying Core Reference Competencies from an Employers' Perspective 403}

Evaluation from a User's Point of View," RQ 34 (Winter 1994): 217-30, available online at http://0find.galegroup.com.library.simmons.edu/gtx/retrieve.do?contentSet [accessed 2 March 2011]; Joan C. Durrance, "Factors that Influence Reference Success: What Makes Questioners Willing to Return?" The Reference Librarian 49/50 (1999), 243-65; Steven Bell and Josh Hadro, "Fish Market 101: Why Not a Reference User Experience?" Library Journal Reference Supplement (Nov. 2010): 6-7, available online at http://web.ebscohost.com/ehost/pdfviewer/pdfviewer?hid=8\&sid=98fb1a6118a8-4ae5-af30-1e3f023d98f5\%40sessionmgr4\&vid=10 [accessed 2 March 2011]; Matt Stock, "The Three R's: Rapport, Relationship, and Reference," The Reference Librarian 51 (Jan./Mar. 2010): 45-52, doi:10.1080/02763870903361995 [accessed 2 March 2011].

8. Ethel Auster and Donna C. Chan, "Reference Librarians and Keeping Up to Date: AQuestion of Priorities," Reference and User Services Quarterly, 44 (Fall 2004): 57-66, available online at http:// web.ebscohost.com/ehost/pdfviewer/pdfviewer?hid=8\&sid=98fb1a61-18a8-4ae5-af30-1e3f023d98 f5\%40sessionmgr4\&vid=6 [accessed 2 March 2011]; Mary M. Nofsinger, "Training and Retraining Reference Professionals," The Reference Librarian 39 (1999): 9-19, doi: 10.1300/J120v30n64_02 [accessed 2 March 2011].

9. Mary Ann Kennan, Patricia Willard, and Concepcion S. Wilson, "What Do They Want? A Study of Changing Employer Expectations of Information Professionals," Australian Academic E Research Librarians 37 (Mar. 2006): 17-37, available online at http://web.ebscohost.com/ehost/ pdfviewer/pdfviewer?hid=8\&sid=98fb1a61-18a8-4ae5-af30-1e3f023d98f5\%40sessionmgr4\&vid=5 [accessed 2 March 2011].

10. Reference and User Servicies Association, "Guidelines for Behavioral Performance of Reference and Information Service Providers."

11. Atefeh Noorizadeh Ghasri and Mozhdeh Dehghani, "Chat Reference: Training and Competencies for Librarians," Library Philosophy \& Practice 11 (Spring 2009): 1-7, available online at http://web.ebscohost.com/ehost/pdfviewer/pdfviewer?hid=8\&sid=98fb1a61-18a8-4ae5-af30-1e3f 023d98f5\%40sessionmgr4\&vid=25 [accessed 2 March 2011]; Lili Luo, “Toward Sustaining Professional Development: Identifying Essential Competencies for Chat Reference Services," Library and Information Science Research 30 (2008): 298-311, available online at http://0-www.sciencedirect. com.library.simmons.edu/science/article/pii/S0740818808000790\#secx19 [accessed 2 March 2011]; Luo, "Chat Reference Competencies."

12. Wendy Clark, "Reference Service 2.0 Revisited," Refer 26 (Summer 2010): 11-16; Brian S. Mathews, "Looking for What's Next: Is It Time to Start Talking about Library 2.1?" Journal of Web Librarianship 3 (2009): 143-47, doi:10.1080/19322900902905332 [accessed 2 March 2011]; Lorri Mon and Ebrahim Randeree, "On the Boundaries of Reference Services: Questioning and Library 2.0," Journal for Education for Library and Information Science 50 (Summer 2009): 164-75, available online at http://web.ebscohost.com/ehost/pdfviewer/pdfviewer?hid=8\&sid=98fb1a61-18a8-4ae5-af30-1e3 f023d98f5\%40sessionmgr4\&vid=23 [accessed 2 March 2011].

13. Khalid Mahmood, "Competencies Needed for Future Academic Librarians in Pakistan," Education for Information 20 (2002): 27-44, available online at http://web.ebscohost.com/ehost/ pdfviewer/pdfviewer?hid=8\&sid=98fb1a61-18a8-4ae5-af30-1e3f023d98f5\%40sessionmgr4\&vid=17 [accessed 2 March 2011].

14. McCarthy, "Planning a Future Workforce."

15. Kennan, Willard, and Wilson, "What Do They Want?"

16. Knibbe-Haanstra, "Reference Desk Dilemmas"; Mitchell, "The Changing Role of references Services"; Sherrer, "Thriving in Changing Times."

17. Hanrong Wang, Yinggi Tang, and Carley Knight, "Contemporary Development of Academic Reference Librarianship in the United States: A 44-Year Content Analysis," Library and Information Science Research 36 (Nov. 2010): 489-94, doi:10.1016/j.acalib.2010.08.004 [accessed 2 March 2011].

18. Claudene Sproles, Anna Marie Johnson, and Leslie Farison, "What the Teachers Are Teaching: How MLIS Programs Are Preparing Academic Librarians for Their Instructional Roles," Journal of Education for Library and Information Science 49 (2008), available online at http://0vnweb.hwwilsonweb.com.library.simmons.edu/hww/results/external_link_maincontentframe. jhtml?_DARGS=/hww/results/results_common.jhtml.44 [accessed 25 May 2011]; Wang, Tang, and Knight, "Contemporary Development of Academic Reference Librarianship."

19. Auster and Chan, "Reference Librarians and Keeping Up to Date"; Lesley S.J. Farmer, “The Life Cycle of Digital Reference Sources," The Reference Librarian 50 (Apr./June 2009): 117-36, doi:10.1080/02763870902755957 [accessed 2 March 2011]; Nofsinger, "Training and Retraining Reference Professionals."

20. Nofsinger, "Training and Retraining Reference Professionals."

21. Justina O. Osa, "Managing the 21st Century Reference Department: Competencies," The Reference Librarian 39 (2003): 35-50, available online at http://web.ebscohost.com/ehost/pdfviewer/ pdfviewer?hid=9\&sid=98fb1a61-18a8-4ae5-af30-1e3f023d98f5\%40sessionmgr4\&vid=54 [accessed 2 March 2011]; Felix E. Unaeze, “Leadership or Management? Expectations for Head of Reference 
Services in Academic Libraries," The Reference Librarian 3 (2003): 105-17, available online at http:// web.ebscohost.com/ehost/pdfviewer/pdfviewer?hid=9\&sid=98fb1a61-18a8-4ae5-af30-1e3f023d98 f5\%40sessionmgr4\&vid=55 [accessed 2 March 2011].

22. Denise Adkins and Sanda Erdelez, "An Exploratory Survey of Reference Source Instruction in LIS Courses," Reference \& User Services Quarterly 46 (2006): 50-60, available online at http://0vnweb.hwwilsonweb.com.library.simmons.edu/hww/results/external_link_maincontentframe. jhtml?_DARGS=/hww/results/results_common.jhtml.44 [accessed 24 May 2011]; Denise E. Agosto, Lily Rozaklis, Craig MacDonald, and Eileen G. Abels, "Barriers and Challenges to Teaching Reference in Today's Electronic Information Environment," Journal of Education for Library \& Information Science 51 (Summer 2010): 177-86, available online at http://web.ebscohost.com/ehost/ pdfviewer/pdfviewer?hid=113\&sid=98fb1a61-18a8-4ae5-af30-1e3f023d98f5\%40sessionmgr4\&v id=28 [accessed 2 March 2011].

23. Ronald Powell and Douglas Raber, "Education for Reference/Information Service: A Quantitative and Qualitative Analysis of Basic Reference Courses," The Reference Librarian 20 (1994): 159, available online at http://0-www.informaworld.com.library.simmons.edu/smpp/ content $\sim \mathrm{db}=$ all? content $=10.1300 / J 120 v 20$ n43_13 [accessed 24 May 2011].

24. Powell and Raber, "Education for Reference/Information Service"; Agosto, Rozaklis, MacDonald, and Abels, "Barriers and Challenges to Teaching Reference."

25. Nofsinger, "Training and Retraining Reference Professionals."

26. Agosto et al., "Barriers and Challenges to Teaching Reference"; Yvonne J. Chandler, "Reference in Library and Information Science Education," Library Trends 50 (2001): 245-62, available online at http://0-vnweb.hwwilsonweb.com.library.simmons.edu/hww/results/external_link_maincontentframe.jhtml?_DARGS=/hww/results/results_common.jhtml.44 [accessed 25 May 2011]; Lorri Mon, Eileen G. Ables, Denise E. Agosto, Andrea Japzon, Linda Most, Mike Masnik, and Jeanne Hamann, "Remote Reference in US Public Library Practice and LIS Education," Journal of Education for Library and Information Science 49 (2008): 180-94, available online at http://0-vnweb.hwwilsonweb.com.library.simmons.edu/hww/results/external_link_maincontentframe.jhtml?_DARGS=/hww/results/results_common.jhtml.44 [accessed 25 May 2011].

27. Agosto et al., "Barriers and Challenges to Teaching Reference"; M. Kathleen Kern, "Teaching Reference: Ten Questions from a First Attempt," Reference and User Services Quarterly 48 (2009): 330-33, available online at http://0-vnweb.hwwilsonweb.com.library.simmons.edu/hww/results/ external_link_maincontentframe.jhtml?_DARGS=/hww/results/results_common.jhtml.44 [accessed 25 May 2011].

28. Agosto et al., "Barriers and Challenges to Teaching Reference."

29. Adkins and Erdelez, "An Exploratory Survey of Reference Source Instruction in LIS Courses"; Agosto, Rozaklis, MacDonald, and Abels, "Barriers and Challenges to Teaching Reference."

30. Mon et al., "Remote Reference in US Public Library Practice and LIS Education."

31. Ronald R. Powell and Douglas Raben, "Education for Reference/Information Services: A Quantitative and Qualitative Analysis of Basic Reference Courses," The Reference Librarian 43 (1994): 145-72.

32. Loriene Roy, "Engaging LIS Students in Reference Work through Online Answer Boards," The Reference Librarian 51 (2010): 97-107, available online at http://0-www.informaworld.com. library.simmons.edu/smpp/content $\sim \mathrm{db}=\mathrm{all}$ ? content $=10.1080 / 02763870903579455$ [accessed 25 May 2011].

33. Deborah S. Grealy, "Reference Theory and Practice: Teaching Coping Skills in a Changing Environment," Colorado Libraries 27 (2001): 4-8, available online at http://0-vnweb.hwwilsonweb. com.library.simmons.edu/hww/results/external_link_maincontentframe.jhtml?_DARGS=/hww/ results/results_common.jhtml.44 [accessed 25 May 2011].

34. Sproles, Johnson, and Farison, "What the Teachers Are Teaching."

35. Sproles, Johnson, and Farison, "What the Teachers Are Teaching"; Rebecca Albrecht and Sara Baron, "The Politics of Pedagogy: Expectations and Reality for Information Literacy in Librarianship," Journal of Library Administration 36, no. 1-2 (2002): 71-96. 